\title{
EVIDENCE THAT AMPICILLIN AND STREPTOMYCIN CAN SUPPRESS AUTOTOMIC
} BEHAVIOUR IN RATS

\author{
KRŠLJAK ELENA* and STAJČIĆ Z** \\ ${ }^{\star}$ Department of Physiology, ${ }^{*}$ Clinic of Maxillofacial Surgery, Faculty of Stomatology, \\ University of Belgrade
}

(Received 9. January 2004)

Autotomy is a phenomenon of deafferentation of the rat limb by transection of the sciatic and saphenous nerves, inducing an automutilation of the limb as a response to painful stimuli generated from the amputation neuroma. Autotomy has been proposed as an experimental model for neuralgia pain. The present study was designed to investigate the influence of streptomycin, ampicillin and chloramphenicol applied either in the vicinity of the nerve stump or intramuscularly. The course of autotomy was followed during 8 weeks using the scoring system of Wall et al. (1979). It was shown that streptomycin and ampicillin can suppress autotomy when applied topically whereas systemic use of the investigated antibiotics was efficient only when streptomycin was injected.

Key words: autotomy phenomenon, ampicillin, streptomycin, chloramphenicol.

\section{INTRODUCTION}

Wall et al. (1979) were able to produce automutilation behaviour in rats after the sciatic and saphenous nerves had been transsected. This behaviour of attacking denervated limbs was named the autotomy phenomenon and was taken as an experimental model for neuralgia pain. The advantage of this finding is reflected in the possibility of comparison and representation of pain intensity (Sporel et al., 1991). Based on the extent of the damage to the limb, an autotomy degree scale was formed (Wall et al., 1979). There are two components of painful impulses causing the autotomy phenomenon. According to Wall et al (1979), the first one is the ectopic activity from neuroma formation. The second one, being central, is related to CNS activities (Kaupilla et al., 1991).

Published studies have been focused on substances and drugs blocking pain receptors or excitatory neurotransmitter receptors. According to Puke et al. (1993), opioid application and cryotherapy (Wagner et al., 1995) have been known to reduce the autotomy scores. Seltzer et al. (1991) showed that amitriptilene, a tricyclic antidepressant, reduced autotomic behavior. Yamamoto et al. (1992) suppressed autotomy with oral morphine in the sciatic nerve in rats. Stajcic (1992) showed that topically applied streptomycin significantly reduced 
the autotomy phenomenon after sciatic nerve section in rats. Also, Stajcic et al. (2002) showed that morphological changes may be responsible for the antineuralgic effects of streptomycin. Suaudeau et al. (1989) prevented automutilation behavior in rats by subcutaneous application of chloramphenicol and amoxicillin. According to Best et al. (1999) aminoglycosides, tetracyclines and lincosamides have neuromuscular blocking side effects.

This study was designed to investigate whether the mode of application of antibiotics can have an influence on the rate of suppression of the autotomic phenomenon in rats.

\section{MATERIALS AND METHODS}

\section{Experimental animals}

Study approval was obtained from the Ethical committee of the Faculty of Stomatology, Belgrade University. The study was performed on 60 female Albino Wistar rats, weighing 200-300 grams. The experiment was terminated by etherisation of the animals.

\section{Experimental procedure}

The animals were anaesthetized with an intraperitoneal injection of Nembutal (35 mg/kg).

The sciatic nerve was identified, isolated and transected posterior to the last side branch. The saphenous nerve was also transected and blood vessels ligated. The proximal end of the sciatic nerve was pulled into a $10 \mathrm{~mm}$ length of polyethylene (PE) tube which was secured in place with a suture and closed with sterile bone wax on the distal part of the tube (Fig. 1). Two weeks after the surgical

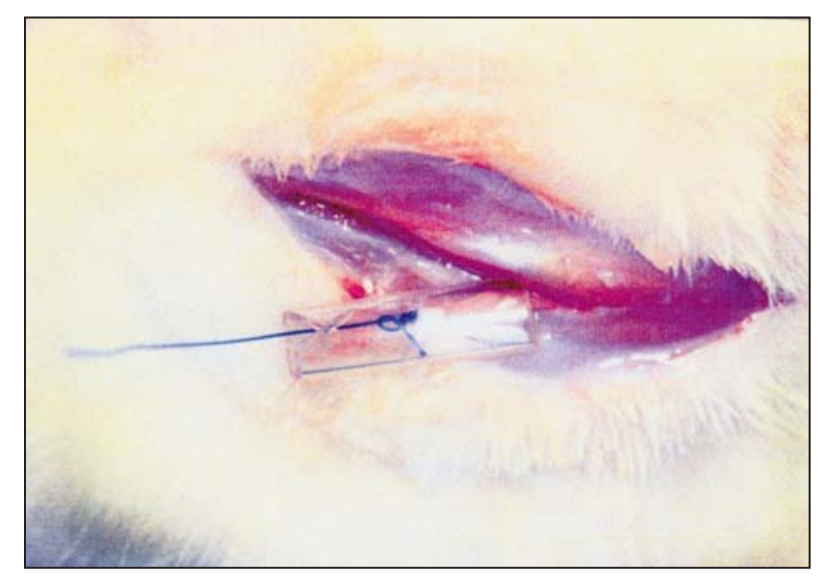

Figure 1. The proximal end of the sciatic nerve is placed into the polyethilene tube 
Acta Veterinaria (Beograd), Vol. 54. No. 2-3, 145-152 2004.

Kršljak Elena et al. Evidence that ampicillin and streptomycin can

suppress autotomic behaviour in rats

procedure animals usually started biteing their claws and toes of the feet. Autotomic behavior was measured by the extent of the limb lesions expressed as the autotomy score according to Wall et al. (1979). Scores from one to five $\left(A_{1}-A_{5}\right)$ are for bitten claws (Fig. 2). Scores from five to ten $\left(A_{5}-A_{10}\right)$ represent bitten phalanges (Fig. 3). The maximal autotomy score $\left(A_{13}\right)$ represents the whole foot bitten (Fig. 4). All rats were examined daily in the first two weeks.

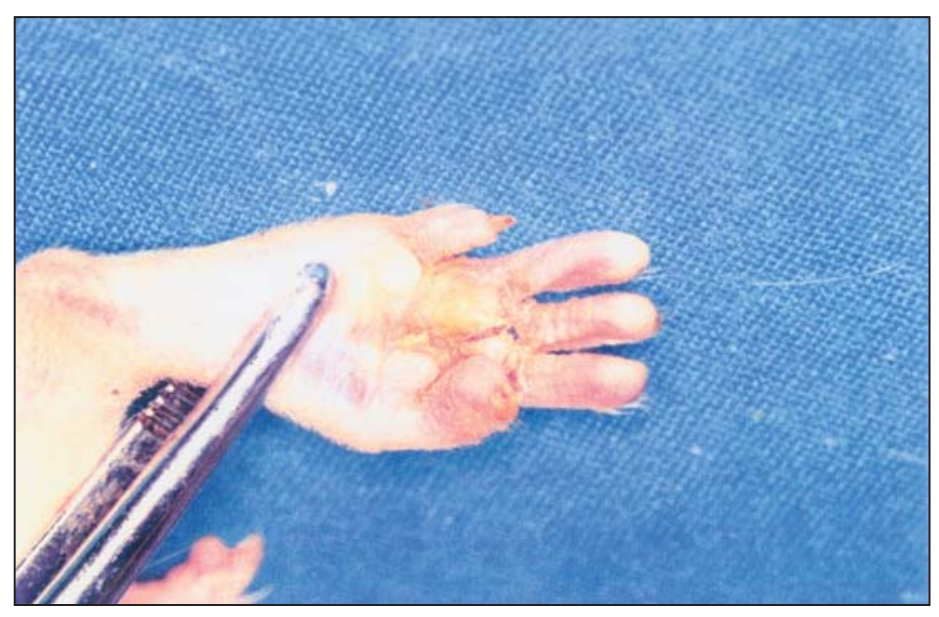

Figure 2. Four nails bitten

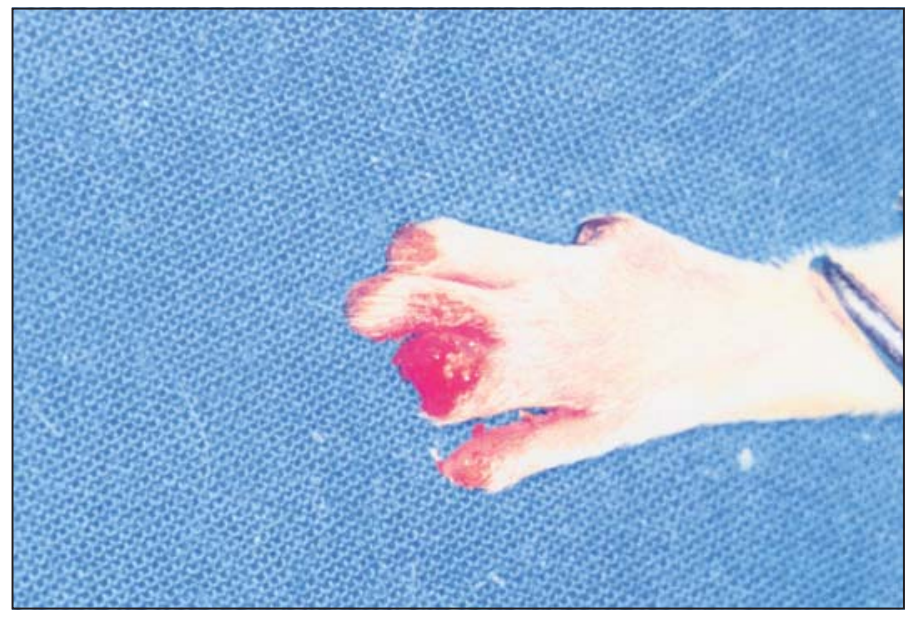

Figure 3. An animal limb without two phalanges 


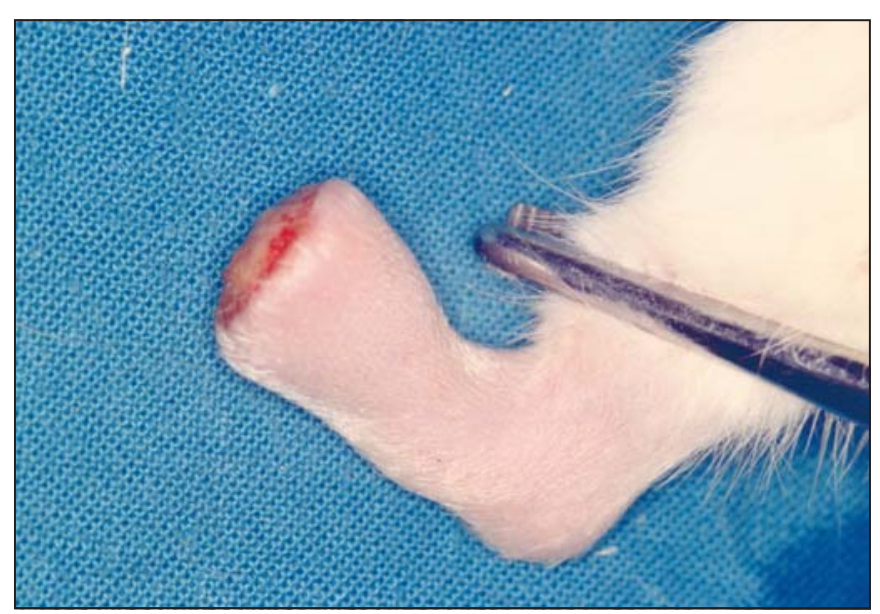

Figure 4. The whole foot bitten off

\section{Experimental groups}

Two experimental groups were formed when the animals exhibited autotomy scores between $A_{1}$ to $A_{5}$. In Group 1 , the animals were operated on again according to the previous protocol and tissue fluid was carefully aspirated from the PE tube with a 27-gauge needle, taking care not to touch the nerve. 0.01 $\mathrm{ml}$ of $50 \%$ solution of streptomycin, ampicillin, chloramphenicol and saline were slowly injected into the PE tube, beside the nerve in the different groups of animals. The animals were examined for autotomy score on a weekly basis during 8 weeks or until the autotomy score reached $A_{13}$. In Group 2, when the animals exhibited autotomy scores between $A_{1}$ to $A_{5}$, streptomycin, ampicillin, chloramphenicol and saline as a control were applied intramuscularly in daily doses of $250 \mathrm{mg} / \mathrm{kg}$ in a two-week period, and the autotomy score was followed during the experimental period.

\section{Tested drugs}

The following drugs were used:

Ampicillin (Pentrexyl-Galenika), Streptomycin (Streptomycin sulfateGalenika), Chloramphenicol sodium- Mediochemine-LTD, Saline (Zdravlje, Leskovac) and Nembutal (Sodium pentotal-Galenika)

\section{Statistical evaluation}

The weekly mean autotomy scores and standard deviations of the mean were calculated for each group. The Mann-Whitney test was used to test differences between the groups. 


\section{RESULTS}

Streptomycin injected in to the PE tube, in Group 1, suppressed the autotomy scores during the entire postinjection period (Table1). At the eighth postinjection week, none of rats from this group reached the maximal autotomy score.

Table 1. Autotomy scores after antibiotics or saline applied postoperatively in the PE tube

\begin{tabular}{|l|c|c|c|c|}
\hline \multirow{2}{*}{\begin{tabular}{c}
\multirow{2}{*}{$\begin{array}{c}\text { Statistical } \\
\text { parameters }\end{array}$} \\
\cline { 2 - 5 }
\end{tabular}} & \multicolumn{4}{|c|}{ Antibiotics 0.01ml - 50\% solution } \\
\hline \hline No. of animals & 15 & 15 & $\begin{array}{c}\text { chlo- } \\
\text { ramphenicol }\end{array}$ & saline \\
\hline Minimal autotomy score & 1.00 & 2.00 & 5.00 & 15 \\
\hline $\begin{array}{l}\text { Maximal autotomy } \\
\text { score }\end{array}$ & 7.00 & 13.00 & 13.00 & 13.00 \\
\hline $\begin{array}{l}\text { Average value of the } \\
\text { autotomy score }\end{array}$ & $4.00^{* * *}$ & $7.07^{* *}$ & 10.13 & 10.33 \\
\hline Standard error & 1.69 & 2.91 & 2.97 & 2.99 \\
\hline
\end{tabular}

MANN-WHITNEY z -TEST-

$* * * p<0.001$ Statistical significance comparing streptomycin to saline

$\star * p<0.01$ Statistical significance comparing ampicillin to saline

Nine animals (60\%) did not change their autotomy score until the end of the experimental period (Table 2).

Table 2. Autotomy score changes after streptomycin was administered postoperatively

\begin{tabular}{|c|c|c|c|c|c|c|c|c|}
\hline $\begin{array}{c}\text { Autotomy } \\
\text { score before } \\
\text { re-operation }\end{array}$ & \multicolumn{6}{|c|}{ Autotomy score at the end of experimental period } & \multirow{2}{*}{$\begin{array}{c}\text { No. of } \\
\text { animals }\end{array}$} \\
\cline { 2 - 9 } & $\mathrm{A} 1$ & $\mathrm{~A} 2$ & $\mathrm{~A} 3$ & $\mathrm{~A} 4$ & $\mathrm{~A} 5$ & $\mathrm{~A} 6$ & $\mathrm{~A} 7$ & 2 \\
\hline $\mathrm{A} 1$ & 1 & 1 & & & & & & 5 \\
\hline $\mathrm{A} 2$ & & 2 & 1 & 1 & 1 & & & 1 \\
\hline $\mathrm{A} 3$ & & & & & & 1 & & 2 \\
\hline A4 & & & & 2 & & & & 5 \\
\hline A5 & & & & & 4 & & 1 & 5 \\
\hline \hline $\begin{array}{c}\text { Number of } \\
\text { animals }\end{array}$ & 1 & 3 & 1 & 3 & 5 & 1 & 1 & 15 \\
\hline
\end{tabular}

Number of animals without changes of autotomy score 
Statistical significance showed in the animals where ampicillin was injected in the PE in relation to saline $(p<0.01)$, but not when chloramphenicol was compared with saline (Table 1). When animals were treated with antibiotics and saline systemically in Group 2, only streptomycin suppressed the autotomy score when compared with saline (Table 3).

Table 3. The autotomy score after antibiotics were applied systemically

\begin{tabular}{|c|c|c|c|c|}
\hline \multirow{2}{*}{$\begin{array}{c}\text { Statistical } \\
\text { parameters }\end{array}$} & \multicolumn{4}{|c|}{ Antibiotics $250 \mathrm{mg} / \mathrm{kg}$} \\
\cline { 2 - 5 } & streptomycin & ampicillin & $\begin{array}{c}\text { chloram- } \\
\text { phenicol }\end{array}$ & saline \\
\hline \hline No. of animals & 15 & 15 & 15 & 15 \\
\hline $\begin{array}{c}\text { Minimal } \\
\text { autotomy score }\end{array}$ & 1.00 & 5.00 & 2.00 & 1.00 \\
\hline $\begin{array}{c}\text { Maximal } \\
\text { autotomy score }\end{array}$ & 13.00 & 13.00 & 13.00 & 13.00 \\
\hline $\begin{array}{c}\text { Average value } \\
\text { of the autotomy } \\
\text { score }\end{array}$ & $4.73^{\star}$ & 9.33 & 10.27 & 8.20 \\
\hline Standard error & 3.79 & 3.13 & 3.84 & 4.57 \\
\hline
\end{tabular}

* MANN-WHITNEY z-TEST

$\mathrm{P}<0.05$ Statistical significance comparing streptomycin to saline

\section{DISCUSSION}

The prevailing opinion in the literature is that the autotomy phenomenon is caused by painful impulses originating from neuroma at the proximal end of the cut nerve (Abbot et al., 1991). Based on the current findings it can be strongly suggested that an artificially created neuroma in the closed PE tube is directly responsible for the autotomic behavior in experimental animals, since the latency period of two weeks corresponds to the time required for a neuroma to be formed. It was established that many antibiotics including aminoglycosides block neuromuscular transmission, decreasing acetylcholine release or postinjectional sensitivity (Best et al., 1999). However, a potential peripheral site for drugs effectively reduces autotomy by suppression of the afferent nociceptive imput from neuroma. Stajcic et al. (2002) demonstrated that streptomycin could cause disintegration of the nerve fibers when applied topically on the rat infraorbital nerve. Having in mind this finding and the results obtained in this study, it may be suggested that streptomycin applied postoperatively in the PE tube suppresses the autotomy degree. As a consequence, this protective effect against autotomy found with antibiotics may be interpreted as an analgesic effect. On the other hand, antibiotic agents are not known to have analgesic effects. The action of the antibiotics could also have been related to chronic infection of the wounded limb, 
but standard surgery in rats generally does not use very stringent asepsis care because these animals are very resistant to infections. Therefore, an infection at the surgical site does not appear to be an explanation for the autotomic behaviour. It has also been reported that streptomycin stabilizes the nerve cell membrane (Sokoll and Gergis, 1981) and inhibits acetylcholine release at nerve endings (Alkadhi and Mclsaac,1978). The mechanism of the protective effect of ampicillin against autotomy is largely unknown. It could be suggested that ampicillin as well as streptomycin, produces some degenerative changes of the nerve stump, which have been confirmed by Stajcic et al. (2002). On the other hand, it is interesting that glycerol (hypertonic solution) had a destructive influence on the nerve fibers and consequently reduced the ectopic discharge from the transected nerve by an osmotic effect (Rappaport et al., 1986). In this study we used $50 \%$ ampicillin solution which is hypertonic and would answer for the local influence on the autotomy degree. However, chloramphenicol had the same osmotic concentration but no clear effect on autotomy. Several classes of antibiotics have neuromuscular blocking side effects. These include aminoglycosides, tetracyclines and lincosamides (Pittinger et al., 1970). Significant research has been done to explore the mechanism of antibiotic-induced neuromuscular blockade. The hypothesised mechanisms of neuromuscular blockade for aminoglycosides are based on decreased acetylcholine release or decreased postinjectional sensitivity (Best et al.,1999). This would be explain how streptomycin applied systematically reduced the autotomy score. It has been seen that certain antibiotics also suppress autotomy when injected daily, chloramphenicol and amoxicillin being the most effective ( Sauadeu et al., 1989). These two substances are known to cross the blood-brain barrier at a $50 \%$ rate but in our experiments chloramphenicol and ampicillin did not show any effect on the autotomy degree when applied systemically. The hypothesis could also be advanced that the effect of ampicillin applied postoperatively on the degree of autotomy is the consequence of another side effect, which could be explored, in a further neurophysiological investigation.

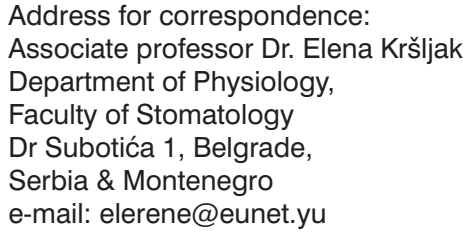

\section{REFERENCES}

1. Abbot FV, Young $S N, 1991$, The effect of tryptophan supplementation on autotomy induced by nerve lesions in rats, Pharmacol Biochem Behav, 40, 301-4.

2. Albe-Fessard D, Giamberardino MA, Rampin f, 1990, Comparison of different animal models of chronic pain, Pain, 3,11-27.

3. Alkadhi KA, Mclsaac RJ, 1978, Ganglion-blocking effects of streptomycin. Arch Int Pharmacodyn Ther, 232, 58-67. 
4. Barbera J, Garcia G, Lopez a, Jose L, 1988, The role of the neuroma in autotomy following sciatic nerve section in rats, Pain, 33, 373-8.

5. Best JA, Marashi Ah, Pollan LD,1999, Neuromuscular blockade after clindamycin administration: a case report, J Oral Maxillofac Surg, 57,600-3.

6. Kauppila T,Pertovara A, 1991, Effects of different sensory and behavioral manipulations on autotomy caused by a sciatic lesion in rats, Exp Neurol, 111, 128-30.

7. Pittinger C, Eryasa Y, Adamson R, 1970, Antibiotics-induced paralysis, Anaesth Analg 49, 487.

8. Rappaport ZH, Seltzer Z, Zagzad D, 1986, The effects of glycerol on autotomy. An experimental model of neuralgia pain, Pain, 26, 85-91.

9. Seltzer Z, Beilin BZ, Ginzburg R Paran Y, Shimko T,1991, The role of injury discharge in the induction of neuropathic pain behavior in rats, Pain, 46, 327-36.

10. Sokoll MD, Gergis SD, 1981, Antibiotics and neuromuscular function. Anaesthesiology, 55, $159-67$.

11. Sporel-Ozakat RE, Edwards PM, Hepgul KT, Savas A, Gispen WH,1991, A simple method for reducing autotomy in rats after peripheral nerve lesions, J. Neurosci Meth, 36, 263-5.

12. Stajčić Z, 1992, The effects of streptomycin on autotomy, Pain , 48, 257-9.

13. Stajčić Z, Saulačić $N$,Dozić $S, 2002$, Effects of streptomycin on the rat infraorbital nerve, $J$ Craniomaxillofac Surg, 30, 5, 304-7.

14. Suaudeau C, Beaurepaire R, Rampin O, Albe - Fessard D,1989, Antibiotics and morfinomimetic injections prevent automutilation behavior in rats after dorsal rhyzotomy, Pain, $5,177-81$.

15. Wagner R, Deleo JA, Heckman HM, Myers, 1995, Peripheral nerve pathology following sciatic cryoneurolyses: relationship to neuropathic behaviors in the rat, Exp Neurol, 133, 254-64.

16. Wall PD, Devor M, Inbal R, Scadding JW, Schonfeld D, Seltzer Z, Tomkiewicz, MM, 1979, Experimental anaesthesia dolorosa, Pain, 7, 103 - 13.

17. Yamamoto T, Mizuguchi T, 1992, Time- dependent effects of oral morphine on autotomy following brachial nerve section in the rat, Neurosci Lett, 141,166-8.

\title{
DOKAZ DA AMPICILIN I STREPTOMICIN MOGU DA SPREČE AUTOTOMIJU KOD PACOVA
}

\author{
KRŠLJAK ELENA i STAJČIĆ Z
}

\section{SADRŽAJ}

Eksperiment je izveden na 60 Albino Wistar pacova kod kojih je izvršeno presecanje $n$. ischiadicus-a i $n$. saphenus-a što je za posledicu imalo pojavu fenomena autotomije. Ovaj fenomen predstavlja eksperimentalni model bola, a ispoljava se samoodgrizanjem delova denervisanog stopala eksperimentalne životinje. Većina autora smatra da supstance i lekovi koji sprečavaju autotomiju utiču i na supresiju bola. Imajući ovo u vidu, cilj naših istraživanja bio je da ispitivane antibiotike primenimo na eksperimentalnom modelu posle ispoljavanja fenomena autotomije, kako bi utvrdili njihovo dejstvo na supresiju ovog fenomena. $U$ isto vreme moguće je razmatrati i eventualno korišćenje ovih lekova u terapiji bola. Rezultati naših istraživanja pokazuju da streptomicin primenjen lokalno i intramuskularno sprečava autotomno ponašanje kod pacova, dok ampicilin sprečava razvoj ovog fenomena primenjen lokalno. Mehanizam delovanja ovih antibiotika još uvek nije u potpunosti razjašnjen, ali to ne umanjuje njihovu eventualnu primenu u terapiji hroničnog bola. 